\title{
The Knowledge and Attitudes of Nursing Senior Students Regarding Traditional and Complementary Medicine
}

\section{Hemşirelik Son Sınıf Öğrencilerinin Geleneksel ve Tamamlayıcı Tıp Konusundaki Bilgi ve Tutumları}

Esma ÖZŞAKER

Citation: Özşaker E. The knowledge and attitudes of nursing senior students regarding traditional and complementary medicine. Van Sag Bil Derg 2021, 14,(2) 153-162. https://doi.org/10.52976/vansagl ik.823136.

Received date: $11 / 08 / 2020$

Accepted date: 25/05/2021

Published date: 30/08/2021
1 Ege University Faculty of Nursing Surgical Nursing Department Izmir, TURKEY.

* Sorumlu yazar: Esma ÖZŞAKER; E-mail: esmaozseker@yahoo.com.

\section{ÖZET}

Amaç: Bu çalışma, hemşirelik son sınıf öğrencilerinin geleneksel ve tamamlayıcı tıp konusundaki bilgi ve tutumlarını incelemeyi amaçlamaktadır.

Materyal ve Metot: Tanımlayıcı tipteki bu çalışma, bir hemşirelik fakültesine devam eden 224 son sınıf öğrencisi ile yapılmıştır. Veriler Öğrenci Tanımlama Formu ve Bütüncül Tamamlayıcı ve Alternatif Tıbba Karşı Tutum Ölçeği (BTATÖ) kullanılarak elde edilmiştir.

Bulgular: Öğrenciler arasında en çok bilinen yöntemler sırasıyla müzik terapisi (\%94,6), akupunktur (\%93,3), hipnoz (\%92,4) ve sülük tedavisi $(\%$ 82,6) idi. Öğrencilerin \%82,1'inin geleneksel ve tamamlayıcı tıp uygulamalarının etkinliğine inandığı, \%74,4'ünün geleneksel ve tamamlayıcı tıp uygulamalarını okulda ayrı bir ders olarak almak istediği belirlendi. BTATÖ ortalama toplam puanı $30.87 \pm 4.83$ idi.

Sonuç: Hemşirelik öğrencilerinin tamamlayıcı ve alternatif tıbba yönelik tutumlarının olumlu ve orta düzeyde olduğu bulunmuştur.

Anahtar Kelimeler: Hemşirelik öğrencisi; Tamamlayıcı tıp; Geleneksel tıp; Hemşirelik eğitimi; Tutum.

\begin{abstract}
Objective: This study aimed to examine the knowledge and attitudes of nursing senior students regarding traditional and complementary medicine.

Material and Method: This descriptive study was conducted with 224 senior students attending a nursing faculty. Data were collected with the Student Identification Form and Holistic Complementary and Alternative Medicine Questionnaire (HCAMQ).

Results: The most well-known methods among the students were music therapy (94.6\%), acupuncture (93.3\%), hypnosis $(92.4 \%)$, and leech therapy $(82.6 \%)$, respectively. It was determined that $82.1 \%$ of the students believed the effectiveness of traditional and complementary medicine practices, $74.4 \%$ of them wanted to take traditional and complementary medicine practices as a separate course in the school. The HCAMQ mean total score was $30.87 \pm 4.83$.

Conclusion: It was found that nursing students' attitudes towards complementary and alternative medicine were positive and moderate.
\end{abstract}

Keywords: Nursing student, Complementary medicine, Traditional medicine, Nursing education, Attitudes.

\section{INTRODUCTION}

Traditional and complementary medicine (T\&CM) has been gaining popularity all over the World (Othman and Fraooqui, 2015). The trend towards T\&CM practices has increased gradually in the solution of health protection and health-related problems (Aktas, 2017). The increasing number of healthcare professionals who are interested in $\mathrm{T} \& \mathrm{CM}$ practices plays an important role in the increase in the number of patients using these treatment methods (Col Araz et al., 2012).
"Traditional Medicine (TM)" can be used in the meaning of using other methods instead of scientific medicine practices. "Complementary Medicine $(\mathrm{CM})^{\prime \prime}$ is the use of traditional medicine products and methods in addition to the treatment protocols of modern medicine (Turan et al., 2010; Ergin et al., 2011; Mollahaliloglu et al., 2015). The terms "Alternative Medicine (AM)" or " $\mathrm{CM}^{\prime}$ " are used synonymously with traditional medicine in some countries. Some societies refer to non-medical prac- 
tices as "AM" and modern medicine supportive therapies as " $\mathrm{CM}^{\prime}$ ". Others define any scientifically unproven treatment intervention as "alternative medicine" (Kayhan and Dilekci, 2020). Today, in Turkey, the common usage is " $\mathrm{T} \& \mathrm{CM}^{\prime}$ ".

After the reports and strategies improved by the World Health Organization (WHO) based on the T\&CM, many countries have made arrangements for the T\&CM (Bicer and Balc1k, 2019). In Turkey, "traditional, complementary, and alternative medicine practices" are regulated by the "Regulation of T\&CM Practice" published by the Health Ministry of the Official Gazette of the Republic of Turkey (Issue: 29158, 27th October 2014). This regulation describes 15 T\&CM practices that can be applied in units and practice centers. These methods are Acupuncture, Apitherapy, Phytotherapy, Hypnosis, Homeopathy, Leech application, Chiropractic, Reflexology, Mug application, Larval application, Mesotherapy, Prolotherapyozone application, Music therapy, Osteopathy (Geleneksel ve Tamamlayıc1 Tip Uygulamaları Yonetmeligi, 2014; Sahin, 2017; Tutuncu, 2017). In this regulation, only certified physicians are authorized for T\&CM applications. Other healthcare professionals with basic education are empowered to assist certified physicians. They participate in practices under their supervision (Somer and Vatanoglu-Lutz, 2017).

Demand for T\&CM applications is increasing in both developed and developing countries. It is used in $70 \%-90 \%$ rates in less some industrialized nations such as Canada, France, Germany, and Italy. It is stated that it is used $42 \%$ in the United States, $48 \%$ in Australia, $49 \%$ in France, $70 \%$ in Canada, and 80\% in Germany. It is used in 60\% -90\% rates in less developed countries such as Ethiopia, Mali, Myanmar, Rwanda, Tanzania, and Uganda (Robinson and Zhang, 2011). In studies conducted in our country, it is seen that the usage rates vary between $25.2 \%$ and $86.3 \%$ (Senol et al., 2020). With the increase in the use of T\&CM methods, healthcare professionals need to increase their knowledge about the effects and reliability of these methods and question the methods used by individuals (Col Araz et al., 2012). Even if the nurses are not authorized to apply, it is very important to have information about these methods in terms of guiding patients and their relatives (Turan et al., 2010; Cevik et al., 2016). Knowledge, attitudes, and approach of health care professionals about T\&CM have a huge importance in the entire life and different cases to improve health, treatment support, and prevent illness (Cinar et al., 2016). Nurses are in a matchless position to bridge the gap between traditional health care and complementary and alternative medicines because the basis of nursing practice is healing and caring (Avino, 2011).

The inclination of people towards T\&CM practices makes nurses, whose purpose is to increase the level of optimal health, inevitable in complementary treatment practices (Aktas, 2017). Nurses are expected to develop nursing practices related to the use of complementary therapies, to determine efficient strategies and to guide healthful/ill individuals to use complementary therapies effectively and correctly (Turan et al., 2010). Due to these important duties, it is necessary to investigate the knowledge and attitudes of nurses and candidate nurses who are in the education process to determine their approach to these methods. For this reason, this study was conducted to examine the knowledge and attitudes of nursing senior students about T\&CM practices.

\section{MATERIAL and METHOD}

\section{Study design and Sample}

A descriptive study design was used in this study. This study was carried out in the nursing faculty of a university in the Ege region of Turkey in May 2018. The universe of the study involves 465 nursing students studying at the last grade of faculty of nursing students in the 2017-2018 education and training season. Sample selection wasn't done and 224 senior students who were at school on the day 
of study and accepted to participate were formed the sample of the study.

\section{Ethical considerations}

This study was approved by the scientific research and publication ethics committee of the relevant university (Protocol no: 2018 / 93). Written permission was obtained from the nursing faculty. Before the data were collected, the purpose of the study was explained to the students and their informed consent was obtained. This study was conducted in accordance with the principles of the Declaration of Helsinki.

\section{Data collection}

After obtaining the necessary permission from the faculty administration, in one lesson hour, students were informed about the research, and the questionnaire was distributed to the students. From the students were required to complete the questionnaire, and then all questionnaires were collected. This process took approximately 15 minutes. All students attending the survey were voluntary.

Data were collected with the Student Identification Form and Holistic Complementary and Alternative Medicine Questionnaire (HCAMQ).

Student Identification Form: The questionnaire was prepared by the researcher after a review of the relevant international literatüre (Erci, 2007; Kilic et al., 2009; Avino, 2011; Altan et al., 2014; Baltaci and Koc, 2018; Sonmez et al., 2018). The questionnaire consisted of two parts and 18 questions. The first part consisted of questions on sociodemographic characteristics of the students, such as age and gender. The second part consisted of questions asking the students whether they were familiar with the T\&CM methods; what they thought about the effectiveness of these methods; whether they would like to be trained in these methods.

Holistic Complementary and Alternative Medicines Questionnaire (HCAMQ): It was developed by Hyland et al. in 2003 and Erci made whose validity/reliable test for Turkish society in the same year. The scale has two subscales called as Holistic Health $(\mathrm{HH})$ and Complementary and Alternative Medicine (CAM). It is a Likert scale and includes 11 questions, the score that can be obtained in this survey is between 11-66. The low score obtained from the scale indicates a positive attitude towards CAM, and a high score indicates a negative attitude towards CAM (Hyland et al., 2003; Erci, 2007). In the study of Erci (2007), Cronbach's alpha value of the scale was found to be 0.72 . In this study, Chronbach's alpha value of the scale was found to be 0.74 .

\section{Data analysis}

Data were analyzed using SPSS version 25.0. Mean, standard deviation, percentages, and frequencies were used to define sample characteristics. A chi-square test was used to examine the relationship between categorical variables. T-test and one-way analysis of variance test (ANOVA) was used to compare the total scores and sub-dimensions of the scale. The value of $p<0.05$ was accepted as statistically significant.

\section{RESULTS}

The age average of the intern nursing students (n: 156) was $22.87 \pm 1.37$ ( $\min 20$-max 32 ) and most participants were female $(86.2 \%)$. It was determined that $87.1 \%$ of the students had a nuclear family structure. Other sociodemographic characteristics were presented in Table 1.

Table 1. Socio-demographic Characteristics of Students.

\begin{tabular}{|c|c|c|c|}
\hline & & $\mathbf{n}$ & $\%$ \\
\hline \multirow[t]{2}{*}{ Gender } & Female & 193 & 86,2 \\
\hline & Male & 31 & 13,8 \\
\hline \multirow[t]{2}{*}{ Marital Status } & Married & 5 & 2,2 \\
\hline & Single & 219 & 97,8 \\
\hline \multirow[t]{2}{*}{ Family Type } & Nuclear family & 195 & 87,1 \\
\hline & Extended family & 29 & 12,9 \\
\hline \multirow{3}{*}{$\begin{array}{l}\text { Place } \\
\text { dence }\end{array}$} & City & 107 & 47,8 \\
\hline & District & 89 & 39,7 \\
\hline & Village & 28 & 12,5 \\
\hline
\end{tabular}


When the level of knowledge of nursing faculty students about T\&CM; The most known T\&CM method was Music therapy (94.6\%), Acupuncture (93.3\%), Hypnosis (92.4\%), Leech therapy (82.6\%), and Phytotherapy (73.2\%), respectively. The least known methods were Prolotherapy (15.2\%), Apitherapy $(16.5 \%)$, and Osteopathy $(18.3 \%)$. It was determined that the most used method by students was Music therapy (49.1\%) and Phytotherapy $(31.2 \%)$ in second place. It was observed that the applications that students most wanted to receive education were Music therapy (83.5\%), Phytotherapy $(79.9 \%)$, Acupuncture (78.6\%), and Hypnosis (Table 2).

Table 2. Student's knowledge of T\&CM methods, usage status, and wanting education on this subject

\begin{tabular}{|c|c|c|c|c|c|c|}
\hline & \multicolumn{2}{|c|}{ Knowledge status } & \multicolumn{2}{|c|}{ Using status } & \multicolumn{2}{|c|}{ Wanting education on this subject } \\
\hline & $\mathbf{n}$ & $\%$ & $\mathbf{n}$ & $\%$ & $\mathbf{n}$ & $\%$ \\
\hline 1.Phytotherapy & 164 & 73,2 & 70 & 31,2 & 179 & 79,9 \\
\hline 2.Acupuncture & 209 & 93,3 & 14 & 6,2 & 176 & 78,6 \\
\hline 3.Cupping & 154 & 68,8 & 30 & 13,4 & 133 & 59,4 \\
\hline $\begin{array}{l}\text { 4.Leech therapy (Hirudother- } \\
\text { apy) }\end{array}$ & 175 & 82,6 & 6 & 2,7 & 130 & 58,0 \\
\hline 5.Hypnosis & 207 & 92,4 & 11 & 4,9 & 161 & 71,9 \\
\hline 6.Ozone therapy & 114 & 50,9 & 4 & 1,8 & 139 & 62,1 \\
\hline 7.Mesotherapy & 58 & 25,9 & 3 & 1,3 & 129 & 57,6 \\
\hline 8.Apitherapy & 37 & 16,5 & - & - & 122 & 54,5 \\
\hline 9.Prolotherapy & 34 & 15,2 & - & - & 122 & 54,5 \\
\hline 10.Osteopathy & 41 & 18,3 & 1 & 0,4 & 128 & 57,1 \\
\hline 11.Reflexology & 137 & 61,1 & 23 & 10,3 & 157 & 70,1 \\
\hline 12.Homeopathy & 48 & 21,4 & 2 & 0,9 & 123 & 54,9 \\
\hline 13.Chiropractic & 45 & 20,1 & 1 & 0,9 & 125 & 55,8 \\
\hline 14.Maggot therapy & 94 & 42,0 & 4 & 1,8 & 117 & 52,2 \\
\hline 15.Music therapy & 212 & 94,6 & 110 & 49,1 & 187 & 83,5 \\
\hline
\end{tabular}

It was determined that $36.5 \%$ of students used $\mathrm{T} \& \mathrm{CM}$ for relaxation and $35.3 \%$ of students used $\mathrm{T} \& \mathrm{CM}$ with internet/social media suggestions. It was determined that the sources of information about the students were mostly internet (68.8\%), family elders $(48.2 \%)$, and $82.1 \%$ of the students believed in the effectiveness of T\&CM. It was determined that only $10.3 \%$ of students received Course/training related to $\mathrm{T} \& \mathrm{CM}$, and $74.6 \%$ of students wanted to take T\&CM as a separate lesson within the scope of the nursing undergraduate curriculum (Table 3 ). 
Table 3. Distribution of students' TCM Related characteristics

\begin{tabular}{|c|c|c|c|}
\hline & & $\mathbf{n}$ & $\%$ \\
\hline \multirow[t]{4}{*}{ Reason for using TCM } & For protection & 19 & 8,3 \\
\hline & For treatment & 51 & 22,6 \\
\hline & For support & 75 & 33,3 \\
\hline & For relaxation & 82 & 36,5 \\
\hline \multirow[t]{4}{*}{ Who recommended the TCM? } & Family & 75 & 33,5 \\
\hline & Doctor / Healthcare worker & 54 & 24,1 \\
\hline & Friend & 55 & 24,6 \\
\hline & Internet / Social media & 79 & 35,3 \\
\hline \multirow[t]{7}{*}{ Source of information } & TV / Newspaper & 75 & 33,5 \\
\hline & Internet & 154 & 68,8 \\
\hline & Scientific / Medical books & 112 & 50 \\
\hline & Friends & 92 & 41,1 \\
\hline & Herbalists & 39 & 17,4 \\
\hline & Family / Relatives & 108 & 48,2 \\
\hline & Doctor / nurse / healthcare worker & 84 & 37,5 \\
\hline \multicolumn{2}{|c|}{ The state of tought wheather TCM methods' effective } & 184 & 82,1 \\
\hline \multicolumn{2}{|l|}{ Took Training/ Course on TCM } & 23 & 10,3 \\
\hline \multicolumn{2}{|c|}{ Want to take TCM as a separate lesson under the curriculum } & 167 & 74,6 \\
\hline
\end{tabular}

When students' opinions about T\&CM practices dents $(73.2 \%)$ responded as "T\&CM can be applied were examined; It is seen that the majority of stuin addition to medical treatment" (Table 4)

Table 4.Students' Opinions about TCM

\begin{tabular}{lll}
\hline \hline & $\mathbf{n}$ & $\%$ \\
\hline \hline It is a threat to public health & 12 & 5,4 \\
Should be under the supervision of a physician & 146 & 65,2 \\
It can be applied in addition to medical treatment. & 164 & 73,2 \\
$\begin{array}{l}\text { It makes one feel good psychologically. } \\
\text { It has not been scientifically tested and should not be recommended. }\end{array}$ & 146 & 65,2 \\
$\begin{array}{l}\text { Nurses should have knowledge about Traditional and Complementary Medi- } \\
\text { cine Practices. }\end{array}$ & 141 & 62,9 \\
$\begin{array}{l}\text { Nurses should advise patients on Traditional and Complementary Medicine } \\
\text { practices. }\end{array}$ & 61 & 27,2 \\
$\begin{array}{l}\text { It is worth trying Traditional and Complementary Medicine Practices before } \\
\text { going to the doctor. }\end{array}$ & 26 & 11,6 \\
$\begin{array}{l}\text { Traditional and Complementary Medicine Practices can delay people getting } \\
\text { the right medical treatment }\end{array}$ & 60 & 26,8 \\
Training on TCM should be provided before and after graduation & 132 & 58,9 \\
\hline \hline
\end{tabular}


The mean total score of the Holistic Complementary and Alternative Medicine Scale was $30.87 \pm 4.83$ $(\min =15, \quad \max =41)$, the Holistic Health sub-dimension mean score was $9.49 \pm 3.35(\min =5$, $\max =20)$ and the CAM sub-dimension mean score was $21.38 \pm 3.60(\min =10, \max =34)($ Table 5$)$.
A statistically significant relationship was found between the CAM subscale score and where they were living $(p=0.047)$. A statistically significant difference was found between the state of thought whether T\&CM methods' effective and the total score of the scale $(\mathrm{p}=0.012)$ (Table 6).

Table 5.The mean scores of HCAM Scale of the students

\begin{tabular}{lllll}
\hline \hline Scale and Sub-dimensions & $\begin{array}{l}\text { Number } \\
\text { of item }\end{array}$ & $\begin{array}{l}\text { Min-Max } \\
\text { possible from } \\
\text { the scale }\end{array}$ & $\begin{array}{l}\text { Min-Max } \\
\text { taken from } \\
\text { the scale }\end{array}$ & Mean \pm SD \\
\hline \hline CAM Sub-dimension & 6 & $6-36$ & $10-34$ & $21,38 \pm 3,60$ \\
Holistic Health Sub-dimension & 5 & $5-30$ & $5-20$ & $9,49 \pm 3,35$ \\
HCAM Total & 11 & $11-66$ & $15-41$ & $30,87 \pm 4,83$ \\
\hline \hline
\end{tabular}

Table 6. Distribution of the total scale and sub-dimension of HCAMQ in groups

\begin{tabular}{|c|c|c|c|c|}
\hline & & $\begin{array}{l}\text { Holistic } \\
\text { Health }\end{array}$ & $\begin{array}{l}\text { Complementary and } \\
\text { Alternative Medicine }\end{array}$ & Total \\
\hline \multirow[t]{3}{*}{ Gender } & Female & $9.38 \pm 3.30$ & $21.27 \pm 3.59$ & $30.65 \pm 4.79$ \\
\hline & Male & $10.16 \pm 3.64$ & $22.06 \pm 3.66$ & $32.22 \pm 4.93$ \\
\hline & & $\mathrm{P}=0.232$ & $\mathrm{P}=0.258$ & $\mathrm{P}=0.094$ \\
\hline \multirow[t]{3}{*}{ Marital Status } & Married & $7.80 \pm 2.58$ & $22.80 \pm 3.27$ & $30.60 \pm 4.44$ \\
\hline & Single & $9.52 \pm 3.36$ & $21.35 \pm 3.61$ & $30.88 \pm 4.85$ \\
\hline & & $\mathrm{P}=0.255$ & $\mathrm{P}=0.376$ & $\mathrm{P}=0.898$ \\
\hline \multirow[t]{3}{*}{ Family Type } & Nuclear family & $9.62 \pm 3.40$ & $21.45 \pm 3.60$ & $31.07 \pm 4.86$ \\
\hline & Extended family & $8.62 \pm 2.94$ & $20.89 \pm 3.60$ & $29.51 \pm 4.48$ \\
\hline & & $\mathrm{P}=0.135$ & $\mathrm{P}=0.437$ & $\mathrm{P}=0.105$ \\
\hline \multirow[t]{4}{*}{ Place of Residence } & City & $9.44 \pm 3.48$ & $21.99 \pm 3.63^{a}$ & $31.43 \pm 5.05$ \\
\hline & District & $9.24 \pm 3.10$ & $20.73 \pm 3.52^{b}$ & $28.97 \pm 4.58$ \\
\hline & village & $10.42 \pm 3.58$ & $21.14 \pm 3.49 c$ & $31.57 \pm 4.43$ \\
\hline & & $\mathrm{P}=0.264$ & $\mathrm{P}=0.047, \mathrm{~b}<\mathrm{a}=\mathrm{c}$ & $\mathrm{P}=0.078$ \\
\hline \multirow{3}{*}{$\begin{array}{l}\text { The state of tought } \\
\text { wheather TCM } \\
\text { methods' effective }\end{array}$} & Yes & $9.32 \pm 3.19$ & $21.14 \pm 3.52$ & $30.46 \pm 4.80$ \\
\hline & No & $10.42 \pm 4.37$ & $22.53 \pm 4.04$ & $32.96 \pm 5.05$ \\
\hline & & $\mathrm{P}=0.209$ & $\mathrm{P}=0.058$ & $\mathrm{P}=0.012$ \\
\hline Took Training / & Yes & $9.21 \pm 2.79$ & $20.43 \pm 3.50$ & $29.65 \pm 4.22$ \\
\hline \multirow[t]{2}{*}{ Course on TCM } & No & $9.53 \pm 3.42$ & $21.47 \pm 3.60$ & $31.00 \pm 4.90$ \\
\hline & & $P=0.669$ & $P=0.192$ & $\mathrm{P}=0.205$ \\
\hline
\end{tabular}

\section{DISCUSSION}

It is important and necessary for nurses to increase their awareness about the prevalence of the use of complementary therapies in the community and to provide communication between the individual and their family and healthcare professionals about these practices (Turan et al, 2010; Aktas, 2017). In this context, it is important to reveal the attitudes 
and opinions of the students regarding the use of T\&CM to guide the nursing students' curriculum studies regarding $\mathrm{T} \& \mathrm{CM}$.

In this study, a majority of the nursing students were familiar with some of the T\&CM methods while some were almost unheard of. It was found that the most commonly known methods were $\mathrm{Mu}$ sic therapy (94.6\%), Acupuncture (93.3\%), Hypnosis (92.4\%), Leech therapy (82.6\%), and Phytotherapy (73.2\%), respectively. The least known TCM methods were Prolotherapy (15.2\%), Apitherapy (16.5\%), and Osteopathy $(18.3 \%)$. In Turkey, similar results were found in studies with medical school students. In the study of Kilic et al. (2009), it was determined that medical students were mostly informed about Acupuncture, Hypnosis, and Massage methods, and the rate of knowing Homeopathy, Osteopathy, and Chiropractic methods were low. Similarly, Sonmez et al, (2018) reported that the most commonly known CAM methods among the medical faculty students; Acupuncture (77.5\%), Cup application (75.3\%), Phytotherapy (67.3\%); the least known methods were Prolotherapy, Homeopathy, Chiropractic, and Osteopathy. In the study of Altan et al. (2014), the least known methods were reported as Chiropractic, Biofeedback, and Ayurveda. In Turkey, the low rate of familiarization of methods such as Prolotherapy, Apitherapy and Osteopathy maybe because these methods are not processed frequently in school and the media. The media and the schools are of great importance in the scientific and popular processing and settlement of T\&CM.

In this study, the most common source for nursing students to obtain T\&CM/CAM information was the internet $(68.8 \%)$ rather than doctor/nurse/healthcare worker (37.5\%), which is similar to the results of other studies (Kilic et al., 2009; Baltaci and Koc, 2018; Sonmez et al., 2018; Wie et al., 2020). Nowadays, in this and other studies, the reason for learning CAM from the internet mostly may be related to the increase in internet and social media use especially among the young together with the current technology development. The im- portance of the media comes to the fore in knowing alternative treatment methods widely. The information that the internet gives about CAM should be questioned in the aspects of accuracy and reliability.

Nursing students are required to receive training on the impact and safety of T\&CM therapies as part of standard undergraduate education. It is important to include these integrative models in the curriculum of nursing students to answer patients' questions about T\&CM in patient care (Avino, 2011; Aktas, 2017). Lack of qualifications in doing this species of treatments or inadequate knowledge of their effects or even its hazards may cause varied problems for patients (Khorasgani and Moghtadaine, 2014). Therefore, as future nurses, nursing students should have enough knowledge of and education on $\mathrm{T} \& \mathrm{CM}$ modalities. In this study, $89.7 \%$ of the nursing students have not received any education on T\&CM. Similarly, in the study conducted by Altan et al. (2014), 98.8\% of medical students were not trained on T\&CM methods. Since the use of $\mathrm{T} \& \mathrm{CM}$ is increasing in our country, it is important that nursing students receive training about $\mathrm{T} \& \mathrm{CM}$ use, effects and reliability during their undergraduate education in order to be effective in patient care (Araz et al., 2012; Aktas, 2017; Baltaci Koc, 2018). In this study, nursing students stated that they found T\&CM methods as effective and that T\&CM related topics should be included in the syllabus, they wanted to be educated about T\&CM. In similar researches carried out before, most of the nursing students stated that the nursing education curriculum should include information and applications on T\&CM and they wanted to be educated about it (Altan et al., 2014; Acikgoz et al., 2016; Baltaci and Koc, 2018). The students' willingness to learn T\&CM suggests the need for T\&CM courses in the faculty curriculum. These results reveal that some changes should be made in the curriculum for T\&CM practices in nursing education. It is expected from the nurses to have knowledge about the effects, side effects and reliability of complementary, and alternative treatments and to direct the 
healthy/unhealthy individuals to use CAM properly and safely (Turan et al., 2010; Cinar et al., 2016). To manage this role properly, they have to get prepared for their roles starting from studentship. Also, it is stated that CAM education had been positive effects on the students' personal health in terms of better sleep, physical exercise, decreased alcohol use, and stress management (Xie et al., 2020).

It was determined in the study that the mean HCAMQ total score was $30.87 \pm 4.83$, the mean holistic health sub-dimension score was 9.49 \pm 3.35 , and the mean CAM sub-dimension score was 21.38 \pm 3.60 . The score that can be taken on the Holistic Complementary and Alternative Medicines Questionnaire are between 11 and 66. The low score obtained from the scale indicates a positive attitude towards CAM. This result from the research shows that the attitudes of nursing students participating in the study towards CAM were positive and moderate. Similarly, Aktas (2017) reported that in nursing students, the mean HCAMQ total score was $31.38 \pm 4.40$, the mean holistic health sub-dimension score was 8.54 \pm 3.06 , and the mean CAM sub-dimension score was 20.42 \pm 3.14 . Baltaci and Koc (2018), reported that the point average of HCAMQ was found as $28.43 \pm 5.05$ and the attitude of the students towards CAM is medium-level and positive, too. Many studies show that nursing students have generally positive attitudes towards CAM. With this respect, the positive attitude and knowledge of nursing students will contribute to patient treatment in terms of providing integrative and reliable care.

In this study; while there was no statistically significant difference between students' gender and the family type and their attitudes towards CAM methods, a statistically significant relationship was found between where they were living and the CAM subscale score. Similar to the results of this study, in the study of Ergin et al. (2011), no significant relationship was found between the gender, family type, and socio-economic status of the spe- cialty and medical students and their attitudes towards CAM methods. However, it was determined that those who lived in the village for a long time had a positive attitude towards CAM. Xie et al. (2020), the female students held a more positive attitude toward T\&CM than the male students $(\mathrm{p}<0.001)$, which is consistent. Baltaci and Koc (2018) reported that female students have a more positive attitude towards CAM than male students $(p<0.001)$. In the literature, no significant difference between CAM attitude and its use according to gender could be observed (Ergin et al., 2011; Araz et al., 2012; Aktas, 2017). It was determined that students who think that T\&CM methods were effective to have a more positive attitude compared to other students $(\mathrm{p}<0.05)$.

In this study, it was determined that the most known and used CAM methods by the intern nursing students were Music therapy. The mean score of HCAMQ indicated that nursing students had a positive attitude toward holistic complementary and alternative medicine. A majority of nursing students wanted to incorporate T\&CM lessons into the curriculum or learn more about T\&CM. The expectations and feedbacks of the nursing students should be taken into consideration in determining the education standards. It is advisable to introduce or increase T\&CM lessons in the faculty curriculum.

\section{Acknowledgement}

This study was presented orally as a verbal statement in the 2. International, 4. National Complementary Therapies and Supportive Care Practices Congress, Izmir, Turkey, 25-28 September 2019. The author wishes to thank all participants for engaging in this study. No financial support was received by the author for the research of this article.

\section{Conflict of interest}

The author declares that they have no conflict of interest. 


\section{Funding}

The author received no financial support for the research, authorship and/or publication of this article.

\section{REFERENCES}

Aktas B. Attitudes of nursing students toward holistic complementary and alternative medicine. JAREN 2017;3(2):55-9.

Altan S, Rahman S, Cam S. The knowledge and attitudes of the medical school students on the methods of alternative and complementary medicine. Turkiye Klinikleri J Med Ethics 2014;22(3):81-8.

Avino K. Knowledge, attitudes, and practices of nursing faculty and students related to complementary and alternative medicine. Holist Nurs Pract 2011;25(6):280-8.

Baltaci N, Koc E. Knowledge, use and attitude of intern nursing and midwifery students with regard to complementary and alternative medicine. Samsun Sag Bil Derg 2018;3(1):10-6.

Bicer I, Yalcın Balckk P. Traditional and complementary medicine: investigation of Turkey and selected countries. Hacettepe J Health Administ 2019;22(1):245-57.

Cevik K, Bolsoy N, Beler M. Information and opinions of nurses on complementary and alternative therapy. Inter Ref J Nurs Res 2016;6:1-15.

Cinar N, Akduran F, Kose D. The attitudes of nursing students regarding the complementary and alternative medicine. Rev Eletr Enf 2016;18:e1174.

Col Araz N, Tasdemir HS, Parlar Kilic S. Evaluation of opinions of the faculty of health sciences students about non medical alternative and traditional therapies. Gümüşhane Univ J Health Sci 2012;1(4):240-51.

Erci B. Attitudes towards holistic complementary and alternative medicine: a sample of healthy people in Turkey. J Clin Nurs 2007;16(4):761-8.

Ergin A, Hatipoglu C, Bozkurt Aİ, Mirza E, Kunak D, Karan $C$ et al. Knowledge and attitudes of residents and medical students on complementary-alternative medicine. Pam Med J 2011;4(3):136-43.

Hyland ME, Lewith GT, Westoby C. Developing a measure of attitudes: the holistic complementary and alternative medicine questionnaire. Complement Ther Med. 2003;11(1):33-8.

Kayhan M, Dilekci E. Evaluation of the applications of traditional and complementary medicine in the perspective of family medicine in a tertiary referral center. Med-Sci 2020;9(1):216-20.

Khorasgani SR, Moghtadaie L. Investigating knowledge and attitude of nursing students towards Iranian Traditional Medicine. Glob J Health Sci 2014;6(6):168-77.

Kilic S, Ogur R, Yaren H, Akkoyun NG, Kupcuk E. Knowledge of and attitudes toward complementary and alternative medicine amongst medical students in a Turkish medical school. Pak J Med Sci 2009;25(2):319-24.

Mollahaliloglu S, Ugurlu FG, Kalaycı MZ, Oztas D. The new period in traditional and complementary medicine. Ankara Med J 2015;15(2):102-5.

Othman CN, Farooqui M. Traditional and complementary medicine. Procedia Soc Behav Sci 2015;170:262-71.

Regulation of Traditional Medicine and Complementary Practices, Official Gazette of the Republic of Turkey, No:29158 (27.10.2014).

Robinson MM, Zhang X. The World Medicines Situation 2011; Traditional Medicines= Global Situation Issues and Challenges. Geneva: WHO.

Sahin S. An overview of traditional, complementary and alternative medicine. Türk Aile Hek Derg 2017; 21 (4): 159-62.

Senol Y, Erdemli B, Demirezen B. Investigation of knowledge and behavior of medical students about traditional and complementary medicine. Anadolu Güncel Tip Derg 2020;2(1): 6-12. 
Somer P, Vatanoğlu-Lutz EE. Evaluation of traditional and complementary medicine practices regulations in terms of law and ethics. Anadolu Klin 2017;22(1):58-65.

Sonmez CI, Baser DA, Kucukdag HN. Evaluation of knowledge and behaviors of traditional and complementary medicine of medical school students. Konuralp Tip Derg 2018:10:278-81.

Turan N, Ozturk A, Kaya N. A New Responsibility in nursing: complementary therapy. Maltepe Univ J Nurs Sci Art 2010:3(1):93-8.
Tutuncu An Overview of Alternative and Complementary Medicine Practices. Medicine Has No Alternative! Traditional Alternative and Complementary Medicine Practices Book, November 2017, Ankara, Turkish Medical Association Publications.

Xie H, Sang T, Li W, Li L, Gao Y, Qiu W, Zhou H. A Survey on perceptions of complementary and alternative medicine among undergraduates in China. Evid Based Complement Alternat Med 2020;12:1-8. 